\title{
Demam Boyband BTS Di Kalangan Mahasiswa Baru 2019 Fakultas Ilmu Sosial Universitas Negeri Malang
}

\author{
Deva Kurnia Rahmawati1, Luhita Rizkiyana Madhanni², Ananda Nur Azahra ${ }^{3}$, \\ Prabu Soko Arya Fird4, Manover Hayyuna Brimantara Taruna ${ }^{5}$ \\ 1rahmawatideva72@gmail.com \\ 1, 2, 3, 4, 5Universitas Negeri Malang
}

$\begin{array}{ccc}\text { Submitted } & \text { Revised } & \text { Accepted } \\ \text { December 4, 2019 } & \text { June 23, 2020 } & \text { June 23, 2020 } \\ & \text { https://dx.doi.org/ 10.17509/jpis.v29i1.21629 } & \end{array}$

\begin{abstract}
During its development, many of the kpop products that were successfully in demand among teenagers included $a$ boy band. This study raised the theme of BTS boyband fever among teenagers with the object of research being the new students of the Faculty of Social Sciences, Malang State University (FIS UM) in 2019. The purpose of this study was due to the researcher's curiosity about how the enthusiasm of new students in responding to this popular culture fever. In this study, researchers used several relevant concepts and theories, including the concept of group membership by Robert K. Merton. Then researchers also associate with the theory of action by Max Webber and Talcott Parsons, the concept of social action according to Max Webber and also the characteristics of industrial society. From the results of research by digging up information on 10 student informants in the selection of purposive sampling through data collection techniques in the form of interviews, it appears that there is indeed a BTS boyband fever that occurs in new students of FIS UM. Then with the BTS boyband fever this will be correlated with the concept of popular culture and several theories relevant to this topic.
\end{abstract}

Keywords: Popular Culture, Boyband, BTS, New Students, ARM.

\begin{abstract}
ABSTRAK
Pada perkembangannya, banyak produk-produk kpop yang berhasil diminati di kalangan remaja diantaranya adalah boyband. Penelitian kali ini mengangkat tema demam boyband BTS di kalangan remaja dengan objek penelitian adalah mahasiswa baru Fakultas Ilmu Sosial Universitas Negeri Malang (FIS UM) tahun 2019. Tujuan dari penelitian ini dikarenakan kaingintahuan peneliti tentang bagaimana antusiasme dari para mahasiswa baru dalam menyikapi demam kebudayaan popular ini. Pada penelitian ini, peneliti menggunakan beberapa konsep dan teori yang relevan, diantaranya konsep membership group oleh Robert K. Merton. Kemudian peneliti juga mengaitkan dengan teori aksi oleh Max Webber dan Talcott Parsons, konsep tindakan sosial menurut Max Webber dan juga ciri-ciri dari masyarakat industri. Dari hasil penelitian dengan menggali informasi 10 informan mahasiswa pada pemilihan purposive sampling melalui teknik pengumpulan data berupa wawancara terlihat bahwa memang ada demam boyband BTS yang terjadi pada mahasiswa baru FIS UM. Kemudian dengan adanya demam boyband BTS ini nantinya dikorelasikan dengan konsep budaya popular serta beberapa teori yang relevan dengan topik ini.

Keywords: Budaya Popular, Boyband, BTS, Mahasiswa Baru, ARMY.
\end{abstract}

\section{PENDAHULUAN}

Boyband dan Girlband asal Korea Selatan yang membawakan aliran
"KPOP” atau kepanjangan dari "Korean Pop" pada musiknya ini begitu marak diberbagai kalngan mulai dari anak- 
anak, remaja hingga dewasa sekalipun dipenjuru dunia. Sudah banyak prestasi yang mereka torehkan dari situlah banyak orang yang penasaran dan akhirnya mengikuti setiap perkembangan boyband maupun girlband Korea. Kemudian mereka memutuskan untuk menjadi penggemar boyband dan girlband asal korea tersebut. Penggemar Kpop tersebut rela mengeluarkan uang mereka demi mewujudkan eksistensinya sebagai penggemar yakni membeli tiket konser sang idola, serta membeli album album yang telah rilis. Selain itu, banyak dari mereka meniru cara gaya berpakaiannya bahkan sampai tingkah laku keseharian.

Budaya populer adalah budaya yang diproduksi secara komersial dan tampaknya tidak ada alasan untuk mengatakan hal ini akan berubah untuk masamasa yang akan datang. Budaya populer dipandang sebagai maknamakna dan praktik-praktik hasil produksi khalayak populer pada momen konsumsi, dan kajian atas budaya populer menjadi terpusat pada bagaimana ia digunakan [1], . Demam Kpop merupakan salah satu dari dampaknya budaya pop, utamanya di Indonesia sendiri telah banyak para penggemar kpop yang tersebar di berbagai daerah. Terbukti adanya konser salah satu boyband ataupun girlband yang diadakan di Jakarta, tiket konsernya pun habis dibeli para pencinta kpop tersebut. Apalagi Hal tersebut dapat dikatakan sebagai adaptabilitas, adaptabilitas merupakan seseorang yang mampu menyesuaikan diri sebaga kepada umum atau kelompoknya dan orang tersebut memperlihatkan sikap dan perilaku yang menyenangkan, berarti orang tersebut telah diterima oleh kelompok dan lingkungan [2], [3]. Maka dari itu Budaya
Pop utamaya pada Kpop itu sendiri telah mampu beradaptasi ke dalam wilayah dominasi. Tidak bisa dipungkiri jika hal tersebut terjadi, karena memang mereka mengikuti alur trend pada saat ini atau dapat sebagai profitabilitas yang merupakan tolak ukur di masyakarat tersebut [3], [4].

Terdapat beberapa jurnal lainnya yang telah peneliti temukan yang membahas mengenai pengaruh Budaya Pop itu sendiri terhadap gaya hidup [5], pola konsumsi [6], perubahan perilaku [7], serta kehidupan sosial para penggemar dari Kpop tersebut.

Dalam jurnal yang peneliti temukan menyatakan bahwa budaya Korea dapat mempengaruhi gaya hidup penggemarnya khususnya di kalangan mahasiswa dimana mereka gemar menonton tayangan Korean Wave, karena memiliki daya tarik tersendiri seperti kegantengan dan kecantikan paras wajah para artis Korea. Kemudian mereka yang gemar budaya Korea ikut bergabung ke dalam salah satu komunitas Ever Lasting Friends yang terjadi di daerah Surabaya [8] [9]. Adapun pengaruh budaya konsumtif yang terjadi di Manado terhadap anak muda yang mana mereka terobsesi dengan fashion style Korea modern yang dibawakan para artis Korea yang berdaya jual tinggi. Sehingga para penggemar selalu mengikuti alur perkembangan budaya Korea tersebut.

Maka dari itu peneliti tertarik untuk meneliti Demam BTS dikalangan maba FIS UM 2019, yang memang sebelumnya belum pernah diteliti oleh para akademik lainnya. Peneliti mengkaji lebih spesifik yakni pada salah satu Boyband asal korea selatan BTS, yang dimana memiliki banyak penggemar yang dikenal dengan nama "ARMY". Peneliti tertarik apakah terdapat ARMY dikalangan maba FIS UM 2019 ini dan 
juga bagaimana reaksi para ARMY tersebut terhadap idolaya yang sedikit banyak mempengaruhi kehidupan mereka.

\section{KAJIAN LITERATUR}

Para penggemar adalah bagian paling tampak dari khalayak teks dan praktik budaya pop. Penggemar selalu dicirikan sebagai suatu kefanatikan yang potensial. Hal ini berarti bahwa kelompok penggemar dilihat sebagai perilaku yang berlebihan dan berdekatan dengan kegilaan. Jenson menunjukkan dua tipe khas patologi penggemar; individu yang terobsesi dan kerumunan histeris [10], [4]. la berpendapat bahwa kedua figur itu lahir dari pembacaan tertentu dan kritik atas modernitas yang tak diakui dimana para penggemar dipandang sebagai simptom psikologis dari dugaan disfungsi sosial. Para penggemar ditampilkan sebagai salah satu dari 'liyan' yang berbahaya dalam kehidupan modern. 'Kita' ini waras dan terhormat, 'mereka' itu terobsesi dan histeris [11], [10].

Penggemar dipahami sebagai korban-korban pasif dan patologis dari media massa. Media massa mengkonstruksikan wacana kepada penggemar dan membentuk theatre of mind mereka. Hal ini menyebabkan penggemar tidak bisa mendiskriminasikan dan menciptakan jarak antara diri mereka dan objek-objek kesenangan. Stereotip yang paling umum misalnya adalah kelompokkelompok gadis dan perempuan histeris yang meneriaki para selebritis idola mereka, kelompok penggemar yang saling bersaing mengadopsi gaya idolanya atau kelompok penggemar yang rela melakukan apa saja demi bertemu idolanya [12], [13].

Kelompok penggemar (fandom) dipandang sebagai simptom (patologis) yang tampak dari kemungkinan runtuhnya budaya, moral dan sosial yang tak terelakkan lagi mengikuti transisi dari masyarakat pedesaan dan agrikultural menuju masyarakat industrial dan urban. Pada tahapnya yang paling lunak, kelompok penggemar merepresentasikan satu upaya yang putus asa untuk mengompensasikan kelemahan kehidupan modern. Fandom cenderung selalu mengejar kepentingankepentingan, memamerkan selera dan preferensi sehingga sangat pas untuk berbagai teks dan praktik budaya pop. Para khalayak ini dapat dikatakan memamerkan kesenangan mereka hingga menimbulkan rasa emosional, sementara khalayak dominan senantiasa mampu menjaga jarak dan kontrol estetik yang terhormat [14], [15]. Hal ini memperlihatkan bagaimana pasifnya khalayak penggemar budaya pop dalam menerima isi media, sehingga mereka mau 'menggilai' sesuatu yang dianggap tidak mempunyai nilai estetika seperti halnya budaya dominan. Namun Jenson tidak sependapat dengan istilah khalayak yang pasif sebab menurutnya, pandangan ini terbentuk karena adanya dominasi pemikiran sosial dari kelompok masyarakat yang lebih dominan. Menurut Jenson, terdapat tiga ciri utama dalam menandai moda pemberian makna budaya penggemar dalam teks-teks media, yaitu: (1) cara penggemar menarik teks mendekati ranah pengalaman hidup mereka; (2) peran yang dimainkan melalui pembacaan kembali dalam budaya penggemar; (3) proses yang memasukkan informasi program ke dalam interaksi sosial secara terus menerus [16]. 
METODE PENELITIAN

Penelitian kali ini menggunakan metode dan pendekatan kualitatif deskriptif. Karena pada penelitian ini, peneliti ingin menemukan data yang mendalam menurut sudut pandang para informan yang telah dipilih. Dalam penjabaran hasil penelitian menggunakan analisis deskriptif yang mana disini penjabaran dilakukan dengan penjelasan yang naratif dan mendeskripsikan secara rinci tentang bagaimana data telah diperoleh.

Teknik yang dipilih dalam mengumpulkan data adalah dengan Teknik wawancara melalui pemilihan sampel berupa purposive sampling. Pada teknik wawancara ada beberapa pertanyaan yg tidak mengacu dengan panduan wawancara, dimana pertanyaan itu peneliti ajukan pada informan saat sedang proses wawancara agar peneliti dapat menggali lebih dalam dari beberapa jawaban yang sudah mereka utarakan. Pada pemilihan sampel ini dibutuhkan ciri-ciri dan informasi khusus yang memiliki korelasi dengan topik dari penelitian ini. Kemudian dari pemilihan sampel ditemukan 10 informan dari tiaptiap jurusan yang ada di Fakultas Ilmu Sosial Universitas Negeri Malang. Dalam penelitian ini, peneliti juga mencantumkan panduan wawancara sebagai acuan peneliti dalam melakukan wawancara yang sesuai dengan prosedur dalam penelitian ini.

\section{HASIL DAN PEMBAHASAN}

Peneliti memilih 10 informan dari lima jurusan yang ada di Fakultas IImu Sosial, yang terdiri dari jurusan Sosiologi, Pendidikan IPS, Pendidikan Kewarganegaraan, Sejarah, dan Geografi. Dari kelima jurusan tersebut peneliti mengambil masing-masing dua informan. Informan kami tersebut keseluruhan berjenis kelamin perempuan. Dimana sebagian besar penggemar boyband BTS adalah perempuan. Informan pertama dari jurusan sosiologi mengatakan bahwa sebelum menggemari boyband BTS ia sudah tertarik pada budaya Korea dan beberapa boyband lain yang sedang tenar saat itu. Kemudian dari ketertarikan tersebut mulai melirik boyband BTS yang sedang tenar pada tahun 2015. Namun keterarikan terhadap boyband BTS dimulai sejak SMA pada tahun 2017, ia terpengaruh dari teman di sekolahnya yang saat itu sedang menonton video musik BTS, dari situ ia menganggap video BTS sangat menarik dan lagu-lagunya sangat menginspirasi kemudian ia mulai tertarik untuk mengetahui tentang BTS lebih lanjut. Namun responden kami tersebut tidak pernah mengeluarkan uang untuk membeli sesuatu yang berkaitan dengan BTS karena ia hanya menganggap BTS sebagai kesenangan belaka.

Ada perbedaan dari responden pertama tersebut dengan responden kedua kami, dimana responden kedua ini sudah menyukai BTS saat sedang tenar di tahun 2015. la sangat menyukai kharisma yang dibawakan para anggota BTS baik dalam video musik maupun perform mereka di panggung konser. Menurutnya dalam setiap video musik BTS selalu ada teori-teori dalam setiap adegannya dan menarik orang yang melihat untuk memecahkan teori-teori itu. Sejauh ini ia sudah pernah menonton penampilan BTS di Jakarta saat itu. Kedua responden kami samasama merasakan manfaat sebagai penggemar BTS, dimana mereka dapat merasakan hal berbeda yang terkandung dalam setiap lagu BTS utamanya lagu mereka yang berkaitan dengan kehidupan. Mereka juga mengetahui perkembangan BTS dimana 
boyband ini mulai tenar pada tahun 2015 di Korea kemudian semakin tenar lagi ketika mereka memenangkan billboard award.

Informan selanjutnya berasal dari jurusan Pendidikan IPS. Informan pertama ini mengatakan ia mulai menyukai BTS sejak 3 tahun lalu masa SMA, tapi sebelumnya ia memang sudah menyukai K-POP. la juga suka budaya Korea. Bahkan ia sempat akan mendaftar beasiswa di Korea. Namun ternyata ia diterima untuk berkuliah di UM. Akhirnya ia memutuskan melanjutkan S1 di UM. Semenjak kelas 2 SMA ia mulai menyukai BTS, bahkan ia pernah mencoba mencover lagu BTS. Ia mulai menyukai BTS di awal trendnya Gen Halilintar mengcover lagu Mic Drop milik BTS, lagunya terdengar enak. Semenjak itu ia mulai mencari tahu perkembangan BTS dari awal debut hingga sekarang. Dengan mendengarkan semua lagu-lagu BTS yang enak dan memiliki makna yang mengena di hati dan kerja keras mereka membuatnya menjadi terinspirasi untuk menghadapi masalah hidup yang dialami, apalagi ia sendiri menceritakan keadaan keluarga yang broken home. Sebagai ARMY dia juga membeli barangbarang yang berkaitan dengan BTS menggunakan uang tabungannya sendiri. la sekarang juga mulai menabung agar bisa membeli tiket konser BTS di Korea.

Dari perkembangan BTS yang ia ketahui selama ini, semakin lama semakin baik ia juga semakin senang mengikuti perkembangannya. Tapi sebenarnya semenjak mereka menang billboard awards BTS mulai berkolaborasi menciptakan lagu dengan artis-artis barat dan ia merasa BTS mulai terpengaruh oleh mereka dan sedikit banyak penyanyi yang berkolaborasi dengan BTS memengaruhi lagu-lagu
BTS. Tapi ia tetap menyukai BTS apalagi sekarang sudah mulai go-internasional. la mengatakan bahwa meskipun ia ARMY, tapi ia pun tidak akan membenarkan perilaku mereka selagi itu salah. Ia hanya mengambil sisi positif dari BTS dan ia sangat bangga menjadi seorang ARMY karena memang mereka sangat menginspirasi kehidupannya, lagu-lagunya pun menyemangati kehidupannya terlepas dari lagu mereka yang berkaitan tentang asmara. la merasakan manfaat yang banyak sebagai ARMY. Lagu-lagu BTS sangat bisa memengaruhi saya dalam menghadapi permasalahan kehidupan yang ada. Bahkan saya sempat mencari tahu beberapa kisah kehidupan seorang remaja SMA ARMY Korea yang sangat mencintai BTS, namun tetap tidak meninggalkan kewajibannya sebagai pelajar.

$\begin{array}{rrr}\text { Menurutnya, ARMY Korea } & \text { Kangat berbeda dengan ARMY }\end{array}$
Indonesia. ARMY Korea terdiri dari 3 tingkatan. Tingkat 1, 2, dan 3. Tingkat 3 adalah yang paling besar, dimana untuk menjadi ARMY tingkat 3 mereka harus mempunyai semua album BTS. Sedangkan pada ARMY tingkat 1 mereka hanya sekedar mengetahui perkembangan BTS. Bahkan untuk naik di tiap tingkatan harus melewati ujian, dimana mereka akan diwawancarai segala hal tentang BTS secara detail. Apabila mereka dianggap berhasil, mereka akan lulus dan naik tingkatan. Jika para ARMY melakukan kesalahan, mereka pasti akan di black list dari ARMY. Contoh kecilnya, missal mereka ketahuan tidak membela BTS tapi malah membela boyband lain. ARMY Korea adalah ARMY garis keras. ARMY Indonesia, mereka lebih susah untuk menemui BTS dan hanya tertentu saja yang bisa menemuinya, berbeda dengan ARMY Korea. 
Berdasarkan penuturannya, kegiatan-kegiatan ARMY sangat positif. Diantaranya, penggalangan dana untuk korban bencana kemudian mendonasikannya, disitu mereka menjual barang-barang tentang BTS yang mereka miliki. Mereka juga merayakan ulang tahun tiap anggota BTS di cafe, disana mereka saling bertukar informasi tentang BTS mereka juga saling akrab satu sama lain.

Suatu ketika ia bahkan sempat goyah, karena temannya ada yang mencela dan menghujatnya sebagai ARMY. Mereka sangat membencinya. Kenapa ia bisa menyukai BTS padahal mereka atheis, dan itu semua tidak sesuai dengan ajaran agama yang ia anut (islam). Namun Keluarga kelurga mereka bahkan sang ibu mendukungnya selagi ia mau bertanggung jawab dengan apa yang dilakukan, missal sebagai seorang pelajar kewajibannya adalah belajar.

Selanjutnya, informan dari jurusan Pendidikan Kewarganegaraan, mengatakan bahwa ia menyukai BTS sejak tahun 2016, dan ia menyukai BTS karena menyukai konsepsi dari BTS itu sendiri, salah satunya juga, BTS selalu terkenal dan berkembang tiap tahunnya. Awal nya menyukai BTS dari konser yang diselenggarakan di berbagai dunia pada tahun 2013-2019 ini. Dengan perkembangan BTS yang ada, ia tetap menyukai BTS. Namun ia tidak menyukai salah satu lagu dari BTS karena dalam lagunya, konsep awal BTS yang hip-hop mulai hilang. Sebagai ARMY, ia pernah mengeluarkan uang untuk membeli case hp, pop socket, tas yang bertema BTS. la juga selalu mengikuti perkembangan boyband BTS hingga saat ini. la sebagai ARMY juga mengikuti perkumpulan ARMY di tingkat kabupaten dan dalam perkumpulan itu ada kegiatan menonton BTS bersama di suatu tempat.

Menurut pemaparannya, ARMY di Korea berbeda dengan ARMY di Indonesia, dimana di Korea para ARMY lebih mengetahui konflik yang ada di BTS dan lebih dekat dengan BTS. Sedangkan ARMY Indonesia, jika ada yang tidak menyukai BTS mereka akan menghujat orang itu. Sebagai penggemar BTS ia sangat bangga. Sebagai ARMY manfaat yang ia dapatkan adalah bisa mendapatkan banyak teman bahkan dari ARMY di berbagai kota. Menurutnya ia tetap mencintai budaya Indonesia karena ia hanyalah menyukai konsep-konsep yang dibawakan BTS.

Informan kedua kami dari jurusan Pendidikan Kewarganegaraan mengatakan bahwa ia sudah menyukai BTS sejak tahun 2014. Awalnya ia menyukai BTS karena lagunya pernah muncul di radio dan ia langsung tertarik dengan lagunya. Selain itu juga ia menyukai dance BTS yang energik dan kompak. Visual dalam setiap video musik mereka sangatlah menarik. Sejauh ini ia mengetahui perkembangan BTS yaitu penggemar BTS yang dahulu sedikit sekarang semakin banyak dan mendunia. Selama menjadi ARMY ia pernah mengeluarkan uang untuk membeli barang berkaitan dengan BTS. Manfaat yang dirasakannya adalah ia bisa mempelajari bahasa asing, dalam hal ini Korea, ia juga bisa mengenal budaya Korea dan mencari teman semakin mudah karena ARMY tersebar diberbagai daerah. Namun sebagai ARMY ia tetap mencintai budaya Indonesia.

Sedangkan informan kedua dari jurusan sejarah, mengatakan bahwa ia menyukai BTS sejak tahun 2018. la menyukai BTS karena salah satu personilnya yang bernama Seok Jin, ia 
juga suka BTS karena mereka dari agensi kecil di Korea yang sekarang sudah mendunia. Namun ia tidak seberapa tahu tentang perkembangan BTS, ia hanya tahu awalnya BTS debut pada tahun 2013 dan mulai mendunia tahun 2015 sampai sekarang. Dari perkembangan yang ada ia sudah berhenti menyukai BTS sejak tahun 2019. Karena menurutnya BTS sudah tidak asik lagi. la mengidentifikasi dirinya sebagai ARMY yaitu join dengan grup ARMY, sebagai ARMY ia tidak pernah mengeluarkan uang untuk membeli barang yang berhubungan dengan BTS ia hanya mengikuti BTS lewat media sosial dan media internet seperti youtube. Menurutnya perbedaan ARMY Korea dengan ARMY Indonesia, ARMY Korea lebih mudah untuk menemui BTS dibanding ARMY indonesia yang jaraknya jauh dari Korea. Manfaat yang dirasakan sebagai ARMY ia jadi lebih banyak koneksi dari berbagai wilayah dan sebagai penghibur diri. Meskipun ia ARMY, ia tetap mencintai budaya Indonesia.

Informan kami dari jurusan Geografi, mengatakan bahwa ia menyukai BTS sejak tahun 2015, ia hanya sekedar menyukai lagu-lagu yang dibawakan BTS dan senang melihat perform yang dibawakan BTS tiap konsernya karena mereka selalu terlihat cool. BTS sejak perkembangannya mereka selalu kerja keras untuk menampilkan performya sejak awal debutnya. Dengan adanya perkembangan BTS itu ia tetap menyukai BTS namun ia tidak terlalu mengikuti setiap perkembangannya. la juga pernah mengeluarkan untuk membeli album BTS. Ia merasakan bahwa BTS bisa menghibur dirinya dari lagu-lagu dan penampilan yang dibawakan. la juga tetap menyukai budaya Indonesia.
Dari hasil wawancara yang peneliti dapatkan, dapat diketahui bahwa di kalangan mahasiswa baru FIS UM ini, ARMY yang fanatik terhadap BTS mereka hanya sekedar menyukai penampilan BTS yang dibawakan pada lagu, konser, maupun video musiknya. Namun tidak dipungkiri tetap ada ARMY yang selalu mengikuti setiap perkembangan BTS bahkan mereka mampu menjadikan BTS sebagai penyemangat hidupnya. Itu semua dapat dilihat dari setiap makna dalam lagu BTS yang cukup mengena di hati. Mereka yang mengidentifikasikan dirinya sebagai ARMY turut mengikuti kegiatan yang ada di setiap perkumpulan ARMY. Dari situ mereka bisa mendapatkan relasi yang beragam dari berbagai daerah. Dapat dilihat bahwa tren K-POP yang ada dapat sangat memengaruhi perkembangan ARMY bahkan di kehidupan tiap individunya.

Sehingga dapat diketahui bahwa budaya KPOP memberikan dampak positif seperti meningkatkan kepercayaan diri yang ada pada penggemar, meningkatkan hubungan antar sesama penggemar dari berbagai wilayah saat sedang kumpul komunitas, dan tidak pantang menyerah dalam menghadapi permasalahan mereka karena semangat yang dibawakan oleh para personil BTS bisa terbawa ke dalam diri para penggemarnya. Namun tidak dipungkiri dampak negatif bisa terjadi apalagi status para ARMY yang masih menempuh pendidikan, dimana ia akan malas bahkan tidak bertanggung jawab atas perannya sebagai pelajar. Selain itu mereka yang terlalu fanatik dan tidak terima apabila idolanya dihina oleh penggemar lain, akan saling cemooh dan menimbulkan keributan.

Berdasarkan dari hasil penelitian diatas, kemudian dapat dijabarkan 
penjelasan antara keterkaitan data yang didapat dengan teori dan konsepsi yang ada dalam budaya popular. Dalam pembahasan ini, peneliti akan mengaitkan beberapa teori yang ada pada sosiologi dimana nantinya akan memiliki keterkaitan dengan temuan dan hasil penelitian yang telah didapat diantaranya, konsep membership dan reference group oleh Robert K. Merton, Kemudian teori aksi dari Marx Weber dan Talcott Parsons, konsep tindakan sosial menurut Marx Weber dalam [17]. kemudian ciri-ciri masyarakat industri yang nantinya akan berkaitan dengan budaya popular.

Kemudian, menurut [5] menjelaskan tentang ciri dari masyarakat industri yang nantinya berimplikasi dengan budaya populer. Berikut adalah ciri-ciri dari masyarakat industri yang mana disini dikaitkan dengan temuan dan hasil penelitian diantaranya:

1. Tren, adalah dimana sebuah hasil dari kebudayaan yang bersifat baru telah diterima dan merambah dan dianut oleh kalangan masyarakat. Hal ini sangat berkaitan dengan temuan data lapangan peneliti. Berdasarkan dari wawancara yang telah dilakukan, para informan mengatakan bahwa mereka memulai menjadi penggemar ketika sedang maraknya budaya k-pop yang masuk ke Indonesia dan kemudian menjadi sebuah tren.

2. Durabilitas, budaya popular merupakan budaya yang terikat oleh masa. Maksudnya, akan ada durasi antara awal dan akhir dari perkembangan suatu budaya popular itu sendiri. Diibaratkan sebagai sebuah gunung. Akan ada tahap permulaan dimana sebuah budaya akan menjadi tren dengan dikenal oleh masyarakat kemudian tahap dimana bagaimana kebudayaan itu akan berada di titik puncak dan lambat laun akan kembali meredup eksistensinya. Kemudian akan ada kebudayaan popular baru yang menginvasi dan mengikis budaya popular yang sebelumnya. Dalam hal ini perkembangan boyband BTS sudah sampai pada tahap puncak ditandai dengan eksistensinya yang tinggi di kalangan masyarakat khususnya remaja.

3. Keseragaman bentuk, maksudnya sebuah budaya popular akan diperkenalkan dan disebar melalui media massa. Kemudian dari sini masyarakat akan menerima dan akhirnya terpengaruh oleh kebudayaan ini. Dalam hasil temuan, para informan yang notabene adalah penggemar akan memiliki keseragaman bentuk baik dari sikap, dan gaya bicara. sebagai contoh adalah para mahasiswi akan melontarkan gaya bicara yang cenderung seperti orang korea.

4. Profitabilitas, pada dasarnya budaya popular adalah cerminan dari masyarakat industri yang mana tujuan laten dari budaya popular ini adalah untuk mendapatkan peluang profit atau keuntungan dari pihak yang membentuk kebudayaan ini. Dalam hasil penelitian, ditemukan bukti bahwasanya para mahasiswi yang menggemari boyband BTS akan mengeluarkan uangnya untuk membeli produk-produk yang dihasilkan oleh boyband BTS itu sendiri dalam hal ini mulai dari paket internet untuk mengetahui perkembangan boyband BTS melalui media masa, merchandise yang berkaitan dengan boyband BTS bahkan hingga menonton konser dari boyband BTS ini sendiri.

5. Adaptabilitas, awalnya budaya ini diterima masuk kedalam masyarakat 
kemudian diterima oleh masyarakat. Budaya popular yang masih awal mulanya diadaptasi bisa jadi dari dimana budaya ini terbentuk. Kemudian budaya ini juga diadaptasi di masyarakat dan menyesuaikan masyarakatnya. Keterkaitan dengan hasil penelitian adalah bagaimana para penggemar menerima kpop sebagai budaya yang baru di kalangan mereka dan kemudian belajar dan saling menyesuaikan dengan perkembangan budaya ini. kemudian kemunculan BTS pada tahun 2013 juga tahap awal adaptasi boyband ini yang kemudian diterima di masyarakat terlebih oleh para responden.

Beragam dari teori sosiologi yang dapat dikaitkan dengan temuan dan hasil adalah teori aksi dari Max Webber dan Talcott Parson (Ritzer,2012). Pada teori ini dijelaskan bahwa menurut Webber, teori aksi sebagai tindakan yang berdasarkan dari pengalaman dan pemahaman atas situasi tertentu. Kemudian menurut Parsons, teori aksi merupakan tindakan akibat dari tuntunan nilai dan norma sosial yang dipengaruhi oleh sistem sosial, sistem budaya, dan masing-masing kepribadian individu. Dalam hal ini berkaitan dengan temuan data di lapangan. Yakni bagaimana para informan akhirnya memosisikan dirinya sebagai penggemar BTS akibat dari pemahaman tentang boyband ini. bagaimana boyband BTS kemudian memperkenalkan diri mereka di ranah masyarakat yang nantinya akhirnya dari sini kalangan masyarakat akan mulai tertarik untuk membuka diri dan bertindak sebagaimana mereka mendefinisikan diri sebagai penggemar. Kemudian dapat juga dikaitkan dengan konsep rasionalitas tindakan sosial oleh Max Webber dalam dalam hal ini, orientasi tindakan sosial dibagi menjadi empat yakni Zwerk Rational, Werkrational, Affectional Action, dan Traditional Action. Peneliti kemudian menelaah dan mendapati empat orientasi tersebut berkaitan dengan hasil temuan diantaranya,

1. Zwerk Rational (Tindakan rasionalitas Instrumental), tindakan ini merupakan tindakan yang ditujukan untuk mencapai tujuan-tujuan rasional dari pelakunya yang kemudian diorentasikan pada instrument atau alat sebagai media dalam pencapaian tujuan. Kaitan dengan hasil penelitian adalah bagaimana para penggemar menggunakan sebuah alat hal ini berarti produk yang mereka konsumsi yang berkaitan dengan boyband BTS. Darisini bisa terlihat bahwa penggunaan alat ini sebagai bentuk dari tujuan mereka untuk bertindak sesuai dengan nilai yang ada di kalangannya dalam hal ini berarti kalangan penggemar boyband BTS.

2. Werkrational Action (Tindakan rasional nilai), maksud dari tindakan rasional nilai adalah tindakan dengan pertimbangan kebaikan dan keburukan dalam kalangan masyarakat yang mana itu berada pada atas kepentingan dari individu. Kaitannya dengan hasil penelitian adalah bagaimana para penggemar tergabung dalam perkumpulan penggemar. Hal ini dianggap sebagai suatu kebenaran yang kemudian secara tidak sadar terbentuk menjadi sebuah nilai apabila mereka memang mengidentifikasikan dirinya sebagai penggemar.

3. Affectional Action (tindakan afeksi), tindakan afeksi menitikberatkan pada dorongan emosional yang muncul pada diri kalangan masyarakat. Perihal wujud emosi bisa dikatakan sebagai 
bentuk perasaan sedih, senang, mengasihi, dan menyayangi. Dalam kaitannya dengan hasil penelitian adalah, para penggemar kemudian akan berusaha untuk melindungi idolanya atau boyband BTS dari segala bentuk kejahatan. Dalam hal ini kemudian muncul istilah afeksi atau perasaan kasih dan saying dari para penggemar dan idola mereka. Selain afeksi yang diterapkan pada boyband BTS sebagai idola mereka, para penggemar juga melakukan fungsi afeksi pada antar penggemar. Hal ini dapat dibuktikan melalui perkumpulan yang dilakukan oleh para penggemar juga sebagai salah satu wujud pengenalan diri dan kemudian terjalinlah sebuah pertemanan yang mana akhirnya juga akan menerapkan fungsi afeksi.

4. Traditional Action (tindakan dipertimbangkan dari tradisi yang ada di masyarakat. Pertimbangan dari tradisi ini kemudian juga berkaitan dengan kalangan penggemar BTS. Peneliti mendapati masih ada tindakan tradisional dari para penggemar berupa kecintaan mereka yang pertama adalah negara Indonesia meskipun apa yang mereka gemari adalah bukan sesuatu yang lokal.

Selain itu, peneliti juga mengkaitkan bagaimana karakteristik dari informan yang mengidentifikasikan dirinya sebagai penggemar boyband BTS. Yakni konsep membership group oleh Robert K. Merton dalam (Soekanto,1982). Konsep ini masuk dalam pembahasan tentang jenis-jenis kelompok sosial. Dalam konsep membership group dijelaskan bahwasanya sebuah kelompok dalam hal ini adalah anggota kelompok secara fisik adalah bagian resmi dari kelompok tersebut. Pembuktian dari temuan data adalah, para informan mengakui bahwa mereka adalah secara fisik merupakan bagian resmi dari anggota kelompoknya. Hasil yang peneliti dapat adalah, tiap-tiap informan tergabung dalam kelompok penggemar baik dari ranah lingkungan sekitar bahkan hingga ranah internasional yang disatukan pada suatu aplikasi penggemar.

\section{SIMPULAN}

Dari jurnal penelitian diatas
dapat disimpulkan bahwa para penggemar BTS atau ARMY di kalangan maba FIS UM 2019 adalah banyak yang menyukai boyband BTS karena banyak hal yaitu dari lagu yang dirilisnya dan ketampanan para personel BTS. Para penggemar BTS banyak yang sekarang sudah tidak lagi mengikuti perkembangan BTS karena banyak hal antaranya genre yang berubah ini yang menyebabkan banyak ARMY yang sudah tidak atau mengikuti perkembangan boyband BTS. Dari hasil temuan juga dapat terlihat bahwasanya informan mengidentifikasikan diri mereka sebagai ARMY melalui berbagai hal seperti bergabung dalam sebuah komunitas, membeli barang-barang yang berkaitan dengan BTS bahkan sampai menonton konser. Kemudian, pembahasan dari penelitian ini dikaitkan dengan teori aksi oleh Marx Webber dan Talcott Parsons bahwasanya mereka mengidentifikasikan sebagai ARMY akibat dari pemahaman mereka terhadap perkembangan K-POP dan boyband BTS itu sendiri. Kemudian konsep membership group oleh Robert K. Merton yang dapat dikaitkan dengan bagaimana para ARMY memembentuk perkumpulan atau komunitas sebagai wujud identitas mereka. Selain itu juga konsep tindakan sosial yang 
berorientasi nilai, afeksi, instrumental, dan tradisional yang memiliki keterkaitan pada bagaimana ARMY menggunakan produk-produk dari boyband BTS dengan tujuan untuk menggemari dan menjaga keteraturan dari kelompok penggemar ini sebagai wujud dari afeksi namun tetap mencintai tanah air sebagai bentuk dari tindakan tradisional mereka. Kemudian perilaku para ARMY juga dapat dianalisis melalui ciri-ciri masyarakat industri bahwasnya adanya keterkaitan antara pola perilaku ARMY dengan ciri adaptabilitas, tren, keseragaman bentuk, profitabilitas, dan durabilitas.

\section{REKOMENDASI}

Sehubungan dengan penelitian ini yang telah dilaksanakan memiliki tekerbatasan mengambil subjek, materi yang sangat spesifik dan metode yang sangat sederhana. Maka peneliti menyarankan kepeda pihak lain untuk melakukan penelitian lanjutan dikenakan pada subjek yang lebih luas materi yang lebih umum dan metode yang lebih relevan sehingga dapat memunculkan hasil penelitian yang lebih baik.

\section{DAFTAR PUSTAKA}

[1] R. Saputra, "Representasi Budaya Populer Dalam Novel Anak B-Jell Cheers Karya Thalia Salsabilla (Tinjauan Sosiologi Sastra)," Bahtera Sastra Antol. Bhs. dan Sastra Indones., vol. 1, no. 3, 2013.

[2] S. D. Gunarsa, Dari anak sampai usia lanjut: bunga rampai psikologi anak. BPK Gunung Mulia, 2004.

[3] T. Flournoy, "Marie Antoinette Obsession," 1992.

[4] N. Hawthorne and N. Hawthorne, "The Birthmark."

[5] O. M. Kaparang, "Analisa gaya hidup remaja dalam mengimitasi budaya pop Korea melalui televisi," ACTA DIURNA Komun., vol. 2, no. 2, 2013.

[6] S. Wulandari, "PERILAKU KONSUMTIF PESERTA DIDIK PENGGEMAR K-POP DI SMA NEGERI 4 SURAKARTA. SOSIALITAS," J. Ilm. Pend. Sos, vol. 8, no. 1, 2018.

[7] D. R. M. Sari, "PENGARUH BUDAYA K-WAVE (KOREAN WAVE) TERHADAP PERUBAHAN PERILAKU REMAJA PENYUKA BUDAYA KOREAN DI BANDARLAMPUNG," 2018.

[8] Y. N. Taqwin, "Perilaku Penemuan Informasi pada Komunitas K-Pop 'Ever Lasting Friends (ELF)' Surabaya," UNIVERSITAS AIRLANGGA, 2017.

[9] J. P. Psibernetika, "MENDENGARKAN SEBAGAI MODEL KOMUNIKASI UNTUK," vol. 9, no. 2, 2016.

[10] F. J. Valenti, "The purity myth," 2011.

[11] A. F. Zakaria, "STUDI TENTANG UPAYA GURU IPS DALAM MENGEMBANGKAN PERILAKU PROSOSIAL DAN MENGURANGI PERILAKU BULLYING SISWA DI SMP (Studi Kasus pada Guru IPS SMP PGRI 1 Jatinangor Kab. Sumedang Jawa Barat)," J. Pendidik. Ilmu Sos., vol. 25, no. 1, pp. 117-123, 2016.

[12] A. W. Wiradimadja, "Penerapan Value Clarification Technique (VCT) Model Role Playing Dalam Mata Pelajaran IPS untuk Menekan Perilaku Bullying Siswa di SMP Negeri 4 Bandung," J. Pendidik. Ilmu Sos., vol. 25, no. 2, pp. 182-187, 2016.

[13] P. Lather, "FERTILE OBSESSION : Validity After Poststructuralism," vol. 34, no. 4, pp. 673-693, 2013. 
[14] F. Fusnika, "Pembinaan civic disposition berbasis nilai-nilai kemanusiaan pada pembelajaran pendidikan kewarganegaraan di sekolah tinggi ilmu Kesehatan kota sukabumi," URNAL Pendidik. ILMU Sos., vol. 23, no. 1, 2014.

[15] P. Krugman, "Competitiveness : A Dangerous Obsession," pp. 2845, 1993.

[16] T. Murdock, G., Petts, J., \& Horlick-Jones, "After amplification: rethinking the role of the media in risk communication," Soc. Amplif. risk, pp. 156-178, 2003.

[17] G. Ritzer, Sosiologi Ilmu Paradigma Ganda. Jakarta: PT. RajaGrafindo Persada, 2012. 